Anna Zamkowska, Prof. Ph.D.

Kazimierz Pulaski

University of Technology and Humanities in Radom

\title{
COOPERATION OF VARIOUS PARTNERS AS A CONDITION OF DELIVERING EDUCATIONAL SUPPORT TO STUDENTS WITH SPECIAL EDUCATIONAL NEEDS
}

\section{Introduction}

Special education since the 1970s has changed from educating students with disabilities in segregated settings to their inclusive education in a nearby school. These changes, however, require the development of new theories and new organisational framework. One of the key ingredients is the development of new collaborative strategies and networks. This process involves inviting many different partners to cooperate in agreeing on goals, which are supporting the successful inclusion of special needs students into the most appropriate educational setting. These key participants of the process of educational support are children, families and schools or other supportive institutions. If an cooperative approach towards supporting special educational needs (SEN) is to be developed, it will need to take account of the individual perspectives of each of its participants. Social changes and legal reforms taking place on the international level over the last thirty years has improved the role of parents in deciding their children's future. Moreover, several models of cooperation have been developed and practiced in different countries - the source of experience and examples for the other ones. The aim of this process is to ensure that students, their families, schools and professional services collaborate more closely and support students with special educational needs more effectively.

The aim of the paper is to describe the main partners in the process of supporting a students with special educational needs, including their parents, schools and other institutions, as well as to present various levels and models of their cooperation. Finally, benefits of cooperation, as well as barriers affecting them are described and analyzed. 


\section{Partners of Cooperation}

\section{Children with SEN}

Conceding that children are the most important participants of the educational support process, its necessary to underline their right to play an active role in making decision about the kind of support that should be delivered to them. This right is ensured in Article 12 of the United Nations Convention on the rights of the Child, which states that:

1. States parties shall assure to the child who is capable of forming his or her views the right to express those views freely in all matters affecting the child, the views of the child being given due weight in accordance with the age and maturity of the child.

2. For this purpose, the child shall in particular be provided the opportunity to be heard in any judicial or administrative proceedings affecting the child, either directly, or through representative or an appropriate body, in a manner consistent with the procedural rules of national law (Newell, 1991:44).

The countries that signed the convention are obliged to adjust their procedures to its demands. For example, in the United Kingdom, the first Code of Practice on SEN introduced guidelines on the issue, advising that schools should "make every effort to identify the ascertainable views and wishes of the school or young person about his or her current and future education (DfE, 1994: para. 2:36). Two main arguments were provided in this document. One of them is practical, admitting that "children have important and relevant information; their support is crucial to the effective implementation of any individual education programme". The second one underlines the principle claiming that "children have a right to be heard" (DfE, 1994, para. 2.35; compare: Gersch 1992:26 after Frederickson, Cline, 2010, p. 9).

It is not easy, however, to implement these assumptions due to impairments in cognitive and communicative skills of some students with SEN. The teachers, and other professionals have some questions concerning this matter. They are not sure in which situations and how should they try to find the child's opinion. There are two kinds of situation in which child's opinion should or may be required. One of them is formal. As Soar et al. (2006) suggest, in formal situations, when important decisions are being taken about individual's future (e.g. meetings to resolve disagreements about SEN provisions), some kind of child advocacy service might be assured. The independence of the advocate would be crucial to the success of such a service. According to Polish legislation psycho-pedagogical support may be provided on the initiative of a student.

The second situation takes place in informal situations when a child, for example, is asked for an opinion related to relationships with peers. 
Another questions concerns the methods of gathering data. Norwich and Kelly (2006) carried out a study on participation of pupils with SEN in decision making about their needs. They found that school ethos was the "outstanding and pervasive" factor determining the measure of support of children's direct participation. As the respondents cognitive and communicating skills varied a lot, various methods, verbal and non-verbal, were used in order to get information. These methods involved listening, scribing children's views or having them drawing pictures and perceiving their non-verbal signs. The opportunities of informal situations, such as trips, were used to talk and listen.

Moreover, the Norwich and Kelly (2006) studies show that not only difficulties in communication could be a barrier to gather a child's views and opinions, but also the protective attitude of the staff. Staff expressed concern that making this group of children responsible for giving their views on important matters affecting them might create new threats for their self-esteem and place a burden on them that they would find too difficult.

There may also be problems in interpreting what children intend to say. This is a case especially when taking into consideration a child's drawings that may be interpreted in many different ways.

\section{Parents of Children with SEN}

Cunningham and Davis (1985 after Frederickson, Cline, 2010, p.16) suggested that the ways in which parent-professional relationships concerning providing special educational support have been described might be characterized in terms of the following three models:

1. An expert model in which professionals are construed as the source of all knowledge about children who have SEN and where parents are cast in the role of passive recipients of advice from the experts.

2. A transplant model in which professionals are regarded as the key decision makers and main source of expertise. However, parents are regarded as a valuable resource and source of active support and intervention for their child. Some of the professionals' expertise can be transplanted to the parents who are taught to carry out programmes at home.

3. A consumer model in which the parent becomes the key decision maker and the professionals offer information and services from which the parent can select according to their needs.

The first model, although unfortunately still practiced, is being replaced by the other ones, not only in a theoretical, but also in a practical way. Legislation recently passed in many UE countries has been used to overcome the imbalance in parent-professional relationships, ensuring parental empowerment and rights. The new Polish law concerning this matter gives parents the right to apply to 
a specialist team from psychological and educational services centers or external experts to start the procedure of making a statement about a child's need of special education. Their agreement is necessary for carrying out necessary psychological, pedagogical and medical examinations. The parents are eligible to take part in the team meetings, and in this way influence their final decisions. If they are not pleased with the suggested form of schooling in the statement, they have a right to apply for its revision (MEN, 2008).

Another new law, passed in 2010, concerns providing different kinds of psycho-pedagogical support by schools and kindergartens. The parents are perceived in it as a part of the support system. They are one of the initiators of the psychopedagogical support provided for their child. The support is given on the basis of their cooperation with other participants of the system. A director is obliged to inform the parents in writing about forms, period and amount of hours set for supporting their child. The parents can put forward to the team their motion to ask for evaluating effectiveness of the forms of support. Moreover, they can not only participate in the team meetings but also propose the participation of other persons, especially a medical doctor, psychologist, pedagogue, speech therapist or other specialist.

Not all the parents are sufficiently prepared to make decisions and cooperate in the system of educational support. Therefore, the law offers them different forms of psycho-pedagogical help concerning the resolution of behavioral and educational problems with their children and the development of childcare skills. Teachers, tutors and specialists may provide them necessary counseling, consultations, workshops and trainings (MEN, 2010b).

In order to ensure the successful parent-professional cooperation, Ebersold (2003) suggests an initial agreement on mutual expectations, roles played by each partner and rules of cooperation between teachers, professionals and parents. The parents should not be perceived only as "clients" of educational services, but rather as partners in the process of education and socialization.

Accepting the general idea of the decisive and important role of parents in the process of providing educational support, it's necessary to admit that its application may, in some situations, become a real challenge. First of all, not all the parents are prepared to cooperate with specialists on an equal basis or be the partners in this process. The second problem concerns mixing their parental role with the roles of specialists. Thirdly, its necessary to notice that not all the parents really know or are willing to consider the best way of supporting their child, and not always take into consideration only the child's best interest. Sometimes the family financial situation becomes more important. Finally, specialists, which traditionally tended to play the main role in the support system, need to be prepared to cooperate with parents in the best possible way. 


\section{Schools, and Psychological and Educational Services Centers}

According to The Thematic Publication on Special Needs Education in Europe (Meijer, Soriano, Watkins, 2003) issued by the European Agency for Development in Special Needs Education and Eurydice Network, "The current tendency in the EU and the candidate countries is to develop a policy towards inclusion of pupils with special educational needs (SEN) into mainstream schools, providing teachers with varying degrees of support in terms of supplementary staff, materials, in-service training and equipment" (Meijer et.al., 2003, p. 7). Poland is one of the countries where significant changes in special education from segregation to an integrated and inclusive education has been taking place since the end of the 1980s.

These changes in educational policy require considerable transformation in the main forms of schooling, especially in developing their new roles. Special schools, the traditional form of educating students with disabilities, apart from remaining in its traditional role, are expected to perform a new role of supporting integrated and inclusive settings. The new tasks, arising from a new role, concerns developing professional base for integration, which involves close cooperation between special and integrated or inclusive settings.

This new role is assigned also to regular schools obliged to provide students with special needs education at the appropriate level, providing adequate specialist support, teaching resources, and in some cases necessary architectural adaptations. Unfortunately, according to Zamkowska (2009), the level of educational support provided in regular schools is either low, or, in some cases, average, which does not ensure an adequate level of education to students with disabilities. By contrast, schools with integrated classes, provide educational support at an either average or high level.

As a result of administrative transformations and the reform of the education system, schools facing these new challenges, received more autonomy in shaping their educational program. Moreover, according to the new regulation on psychopedagogical support (MEN, 2010c), the role of psychological and educational services centers in providing the regular school necessary assistance in carrying out its tasks for students with special educational needs has become considerably more significant. The new regulation obligates the centers to fulfill many specific tasks, e.g. cooperation with a school in identifying children with specific learning difficulties, cooperation with kindergartens and school services in development and implementation of individual, educational-therapeutic programs for students with disabilities and social maladjustments; supporting gifted students; as well as participation in the periodic evaluation of the effectiveness of the implemented programs.

The specific tasks assigned to the centers aim at providing not only special needs students, but also their parents and teachers the appropriate forms and level 
of psycho-pedagogical support. Teachers, with the assistance of professionals from the center should be equipped better to fulfill their tasks, especially those concerning students with special educational needs. Moreover, it is expected that the frequency of consultation of the kindergarten and school teachers with professionals will increase in the framework of their mutual cooperation (MEN, 2010c).

\section{Levels and models of cooperation}

The collaboration may be developed at three different levels: inter-institutional, school and class level.

\section{Inter-institutional Level}

Many different terms are used in the literature to describe the organizational forms of cooperation between institutions. These are networks, families, councils, federations, consortia, pyramids and clusters (Gains, 1996, p. 113). J. Lunt and others (1994 after Gains, 1996, p. 113) organized them in the following three categories:

1. Networks are seen as loose, informal and widespread linkages between schools or groups of teachers. They exist largely for the exchange of ideas and mutual support. By nature, they are temporary; the participants working on specific tasks then disbanding or moving on to some other task.

2. Clusters are groupings that are more formal and permanent. Lunt et. al (1994 after Gains, 1996) describe a cluster as "a relatively stable and long term commitment among a group of schools to share some resources and decision making about an area of school activity. There is a degree of formality in that there are regular meetings of cluster schools to plan and monitor the activity concerned. There is some commitment of resources (e.g. teacher time) and some loss of autonomy implied, since schools will have to negotiate some decisions about this area of activity. Clusters can be single phase (i.e. all primary or all secondary) or multi-phase including special school; their origins can be 'top down' (i.e. local authority initiated) or 'bottom up' (initiated by the schools themselves)."

3. Federations are considered by Lunt et al. to be permanent and extensive and may arise from schools merging under one head teacher and governing body. This is now an increasingly likely possibility with small schools pooling their resources in rural areas.

Gains and Smith (1994 after Gains, 1996, p. 117) developed seven micro models of providing support for students with special educational needs:

- pooling, involving core funding,

- exchange of information between working groups from different schools, 
- exchange of skills between teachers from different schools,

- specialist input in different schools,

- the "carousel" model, in which a specialist ( e.g. support teacher) provides support in different schools on a rotating basis ( it is based on contacts),

- the "magnet" model, in which students move to a special center, e.g. IT base,

- the "caravan" model, in which a travelling teacher moves to different places with special equipment.

It is assumed that it is not easy to agree on common principles of the bilateral agreement, and benefits of this cooperation are not always shared equally. The proponents of inter-institutional cooperation underline mainly its benefits (Gains, 1996, p. 116), such as:

- sharing of information,

- facilitating links between phases of schooling,

- liaising with agencies and other groups,

- developing joint policies,

- maximizing expertise and resources,

- economies of scale in purchases.

The positive results of developing inter-institutional networks of support were recorded in England, Holland and Ireland. In England, cooperation between schools has played an important role in dealing with the problem of the strong competition between schools (Gains, 1996), as well as in further mutual cooperation in the form of an exchange of materials and methods between representatives of schools visiting each other (Ainscow et al. 2003).

The Frederickson, Dunsmuir, Lang and J.Monsen (2004) studies shows that the cooperation of various institutions (local education authorities, schools, special schools, inclusive schools and higher education institutions) in England resulted in both social (the acquisition of appropriate behavior, social acceptance) and educational benefits (better qualifications) for pupils with special needs. Positive results of collaboration between the special schools and other primary and secondary schools was reported also in Ireland. Collaboration of these schools consisted mainly of implementation of joint projects during the lessons and afterclass activities (Walsh, de Paor, 2000).

In the Netherlands in 1993, in order to integrate students with special educational needs to the inclusive schools, the educational law introduced the regional clustering of schools. A typical group consists of 25 regular schools and two special schools. These schools work together in the form of teacher exchanges. This collaboration is possible due to a shared system of services (e.g. shared resources, staff employment and exchange of expertise). Regional groups of schools have initiated various activities aimed at reducing the number of students referred to special schools. The Hofman (1999) studies show that the most effective in achieving this aim were clusters with less special schools, and those where the use of resources was targeted at integration and systematically monitored. 


\section{School Level}

In the 1990s a new model of school planning, called the collaborative consultation model, appeared in educational practice. It is based on the assumption that in terms of solving problems the teacher can achieve more in cooperation with other specialists than by using the ready-made solutions offered by external experts. These solutions are not always effective, because teachers are not involved in their development and the classroom situations are usually very complex.

The cooperation in terms of special education, assumes that two or more persons having expertise will work together on developing appropriate strategies for intervention implemented at the class or school level. The role of consultant can be played by various specialists, e.g. another teacher, a school coordinator, a special educator, speech therapist, psychologist or psychotherapist.

The collaborative consultation model underlines the mutual cooperation of equal team members. All participants are responsible for solving problems, as well as the success or failure of the adopted solutions. This model involves joint planning, sharing of responsibilities, resources and the willingness to invest time and effort to know opinions, values, and the terminology used by other team members.

Two approaches can be distinguished within the collaborative consultation model: direct and indirect. The direct approach is implemented, for example, by joint conduct of lessons by a teacher and a special educator. The indirect approach is involved, for example, when a teacher seeks advice of a speech therapist or a special educator about working with a special needs student (McCormick et al., 1997, p. 172-173). The choice of approach depends on the class, the student's needs and preferences of the teacher.

Some authors, taking into account the above mentioned criteria, distinguish the two different support models:

1. consulting teacher model as a direct approach,

2. and cooperative teacher model or co-teaching as an indirect approach (Idol, 2006).

The above mentioned models concern cooperating in pairs. When cooperation in a larger group is required another two models - special needs coordinator or the support team can be taken into consideration. Both of them are described below.

\section{Special Educational Needs Coordinator}

The position of special educational needs coordinator (SENCO) was introduced in England in 1994 in the "Code of Practice on the Identification and Assessment of Pupils with Special Educational Needs" (DFE, 1994). According to this regulation, every school was obliged to appoint a person responsible 
for coordinating special needs provision for their students. Gains (1994 after Westwood, 2002, p. 207) identified eight key functions set for SENCOs in the Code of Practice:

- administration and management: for example, responsibility for organizing the support system in the school; implementing the school policy; maintaining records; attending meetings and case conferences, obtaining resources and preparing budgets, etc.,

- assessment: identifying students with special educational needs by drawing upon information from a variety of sources; monitoring student progress,

- prescription and planning: preparing and processing Individual Educational Plans (IEPs); matching resources to needs, using assessment data to guide curriculum planning, etc.,

- teaching and pastoral care: directly supporting students with special needs; indirectly supporting students with special needs through team teaching and other forms of collaboration with staff; counselling individual students, etc.,

- curriculum support: helping colleagues adapt programmes, differentiate curricula and prepare resources, etc.,

- liaison: with parents, staff, outside agencies, other schools, etc.,

- training and development: assisting with professional development of colleagues through consultation, in-service workshops, resources, etc.,

- collaboration: working with other co-ordinators in other schools, and with other professionals to assist with IEPs, differentiated curricula and special services provision.

The scope of the tasks set for SENCO is very broad and requires taking multiple roles of a leader, advisor, assessor, program planner, consultant, liaison officer, record-keeper, decision-maker, in-service trainer, etc. To meet the demands of these roles, it is necessary to gain adequate level of expertise and many complex skills (Winter, Kilpatrick, 1998). In the Polish system of special education support, the role of SENCO is not specified, but usually in the integrated schools a vice-director or a special educator plays the role of team coordinator, similar in some ways to the role of SENCO.

\section{Collaborative Team}

According to Thousand and Villa (1992 after McCormick et al., 1997, p. 164) the collaborative team is a group of people who:

- agree to coordinate their work to achieve common, agreed-upon goals,

- hold a belief system that all members of the team have unique and needed expertise,

- demonstrate their belief in parity by alternately engaging in the dual roles of teacher and learner, expert and recipient, consultant and consulted, 
- use a distributed functions theory of leadership wherein the task and relationship functions of the leader are distributed among all members of the group,

- and use a collaborative teaming process that involves face-to-face interaction, positive interdependence, the performance, monitoring and processing of interpersonal skills; and individual accountability.

The size and composition of the team may vary, but in most cases it consists of two to six specialists from various disciplines and parents. There are two kinds of members: core team members and support team members. The core team members are directly involved in the design and implementation of individual educational programs; they take key decisions about the child's support and, therefore, must be together in frequent contact. This group of members usually consists of a student, family members, teachers (special and general educators) and one or more related services professional (speech therapist, physical and/or occupational therapist) and possibly a paraprofessional or classroom assistant.

Support team members are not directly involved in the day-to-day programming. They may participate in the planning or decision making once or twice a year. The support team may consists of a psychologist, a social worker, a doctor and orientation and mobility specialists. Core and support team members share together the key roles of the team, such as, for example, assistance in establishing priorities and an action plan, solving problems, sharing expertise helpful in working with a student, supporting other team members and developing their competence in working with students with disabilities and their families (Rainforth et. al., 1992 after McCormick et al., 1997, p. 166-167).

According to Polish law (MEN, 2010b), a school where a student requiring psycho-pedagogical is educated, organizes a team. The team should be composed of core members such as teachers, tutors and specialists supporting a student. The role of supporting members can be taken by parents and specialists appointed by different partners: parents, a student or a head teacher (e.g. specialists from psychological and educational services centers). The support team members are not obliged to be part of the group, but they can attend team meetings.

Members of effective support groups should gain the knowledge and skills useful to cooperate as a team. Ebersold (2003) underlines, that building a well cooperating team is not achieved spontaneously, but requires much effort and consideration of various differences occurring between the members. First of all, there are differences in dynamics, structure and objectives of the institutions, in which different specialists (e.g. physical therapist, social worker) are employed. The second difference concerns the culture of different professions, e.g. doctors, social workers or teachers. Moreover, their position, e.g. a director and a teacher, is often not formally equal, although it is assumed that all team members are equally important and have the same rights. Furthermore, they do not always share the same expectations and way of fulfilling their role. Team members may also have different views on problems of a child and objectives to be achieved, as well as different 
expectations of the tasks assigned to them. In order to minimize these differences and avoid disagreements, Ebersold (2003) suggests negotiating by team members an initial agreement on their expectations and roles, as well as on principles of mutual cooperation between teachers, specialists and parents. However, parents should not be perceived only as "customers" of educational services, but rather as contributors to the process of learning and socialization of their child.

The Walther-Thomas (1997) studies show that there are several benefits of well functioning support teams both for students and teachers. Students with disabilities benefited from an increase in their confidence and self-esteem, motivation, social responsibility and social achievements. In addition, the class as a whole became a more inclusive community. The special educators, teachers and school headmasters experienced an increase in professional satisfaction, career development, receiving personal support and new opportunities for cooperation.

Apart from various benefits, the respondents mentioned also some problems that were difficult to solve. One of them was the lack of sufficient time for joint planning and preparation activities. This problem, however, was significantly reduced over time, because the teachers worked out common planning strategies and special educators became more aware of both the content and the teacher's expectations. Moreover, if they managed to establish a good relationship, their cooperation went more smoothly.

Another difficulty in implementation of the project was development of a lesson plan suitable for classes with disabled students. On the one hand, the classes should be heterogeneous; on the other, it was necessary to provide students with the adequate support of specialists. It turned out that the positive attitude of the head teacher was crucial in solving this problem as adequate selection of pupils with disability to individual classes was necessary. Pupils with similar possibilities were grouped in the same classes, and less challenged pupils were appointed to one joint class. The appropriate grouping of students helped to reduce the number of classes supported by special educators, facilitating their work.

Another problem concerned an insufficient number of specialists in relation to the large number of pupils with special needs requiring support. The teachers also pointed at the need for further training and insufficiency of funds.

\section{Class Level}

At the class level, the collaborative-consultation model is implemented mainly by cooperation between a class teacher and various partners, mainly a support teacher, but also other teachers, assistants, parents, students and volunteers.

A support teacher supports the process of educating students with special needs in cooperation with the class teacher and other specialists. Both teachers make the diagnosis of a class team (its strengths and weaknesses) as well as needs and abilities of the students (by analyzing a child's documentation, making 
observations, interviewing with parents and professionals). They jointly organize the educational process and cooperate in evaluating its effects.

According to Polish law, support teachers have to be employed in schools with integrated classes, but it is not obligatory for inclusive schools (but only optional) to employ them (MEN, 2010c). Therefore, one of the major problems that an inclusive class teacher faces is devoting a separate time for providing a student individual, additional support, without neglecting the other students. The acceptable solution of this problem is asking for assistance of other persons. These helpers may be peers (peer tutoring) or older pupils (cross-age tutoring), assistants (aids, paraprofessionals), parents, volunteers or students (Westwood, 2002, p. 208-211). Their assistance helps to reduce the amount of time devoted to interaction with the entire class, allowing a teacher to work directly with a special needs student. It is also possible that an assistant supports a child in performing a task appointed by a teacher, while a teacher works with the rest of the class.

Students with special needs can get help from students of the same age (peertutoring) or their elder colleagues (cross-age tutoring). According to Westwood (2002, p. 209), a peer can use more simple and direct language, and demonstrate examples faster and more efficiently than a teacher.

An assistant is another person whose help may be necessary in some cases, especially when a disabled student needs special assistance in daily routines. The assistant can be also involved in overseeing a single student or entire class when they perform tasks appointed by a teacher, but is not expected to evaluate a student' special needs, decide about a task or the content of a lesson. Assistants can also act as a "trusted" adult who has the time to listen to students' stories about their interests and concerns.

Studies and observation suggest that the work of the assistant is of benefit to students. Performing the role of an adviser and a friend, an assistant can contribute to the improvement of their communication skills (Westwood, 2002). Moreover, Woolfson and Truswell (2005) studies shows that as a result of "Classroom Assistant Project" a significant improvement in the quality of education in the entire class was observed. The presence of an assistant had also a positive impact on the personal and social development of students, while parents were encouraged to be more involved in their children education.

The parents can also be involved in helping their children in a class. However, they may not always be good teachers, particularly in relation to their own children. They tend to require from them perfect performance of appointed tasks, and when the errors appear, they sometimes show excessive criticism or require children to work too long on a task. Parents, in order to provide appropriate assistance, should therefore be properly prepared by a teacher to play the role of helpers. The teacher, during a preparatory training, should instruct them how to talk with students, encourage them, listen to their reading attempts, use various games for mastering their reading skills. 
There are several benefits of parental involvement. First of all, parents gain awareness of the objectives and methods used in school, as well as learning techniques that can be applied at home (i.e. how to encourage a child or deal with difficult behaviors). Secondly, parents have an opportunity to share their concerns and interests with other parents, realize that not only their children have special needs. Finally, they gain more self-assurance and develop more positive relations with teachers.

Other possible helpers can be volunteers, usually academic students. If they participate in lessons regularly, teachers may ask them to oversee a small group or individual students.

\section{Conclusions}

Collaboration of various partners is an essential condition for the effectiveness of the educational support provided students with special educational needs within integrated and inclusive education. In recent years, the role of these partners, especially students with special needs and their parents, who in the traditional educational model took the role of recipients rather than partners, has been more and more appreciated. Although the student's role in shaping the process of educational support is limited, due to their deficits, still their opinion about the improvement in educational and social development can be valuable for a support team. Similarly, parents have taken increasingly significant role in decision-making.

Another recognized tendency is development of various models of educational support operating at different levels: inter-institutional, school and class level. This vast array of offers permits the possibility of choosing the most optimal in relationship to the educational needs of a student. Polish law provides only a few of these models - a support teacher and assistant, and - recently introduced, a team model. Due to the lack of wide experience in various forms of cooperation in the Polish educational system, it would be recommended to learn from the experience of other countries by working out several conditions of effective cooperation. In conclusion, the most important ones are the following:

- clarification of purposes of cooperation and its scope, as well as roles and responsibilities of partners,

- creation of an atmosphere of mutual trust in order to enable sharing of uncertainties and difficulties,

- mutual respect: more experienced specialists do not consider themselves as knowing everything "experts",

- openness to learning from others and understanding other members of the team,

- mastering communication and cooperation skills,

- fixing enough time for cooperation and team meetings. 


\section{References}

Ainscow, M., Howes, A., Farrell, P., Frankham J. (2003). Making sense of the development of inclusive practices. European Journal of Special Needs Education, 18(2), p. 227-242.

Code of Practice on the Identification and Assessment of Pupils with Special Educational Needs. (1994). DFE.

Ebersold, S. (2003). Inclusion and mainstream education: an equal cooperation system. European Journal of Special Needs Education, 18(1), p. 89-107.

Frederickson, N., Cline, T. (2002). Special Educational Needs, Inclusion and Diversity. Buckingham, USA: Open University Press.

Frederickson, N., Dunsmuir, S., Lang, J., Monsen, J. J. (2004). Mainstream - special school inclusion partnerships: pupil, parent and teacher perspectives. International Journal of Inclusive Education, 8(1), p. 37-57.

Gains, Ch. (1996). Collaborative Networks: Clustering Local Schools to meet Special Educational Needs. REACH Journal of Special Needs Education in Ireland, 9(2), p. 110-119.

Hofman, R.H. (1999). Contribution of clusters to integration. European Journal of Special Needs Education, 14(3), p. 187-197.

Idol, L. (2006). Toward Inclusion of Special Education Students in general Education. A program Evaluation of Eight Schools. Remedial and Special Education, 27(2), p. 77-94.

McCormick, L., Loeb, D.F., Schiefelbush, R.L. (1997). Supporting Children with Communication Difficulties in Inclusive Settings: School-based language intervention. Needham Heights, USA: Allyn\&Bacon.

Meijer, C., Soriano, V., Watkins, A. (Ed.), (2003). Special Needs Education in Europe. Thematic publication. European Agency for Development in Special Needs Education and Eurydice Network. Retrived from http://www.see-educoop.net/education_in/pdf/special-needs-eu-eduoth-enl-t05.pdf [20.10.2012]

Newell, P. (1991). The UN Convention and Children's Rights in the UK. London, England: National Children's Bureau.

Norwich, B., Kelly, N., (2006). Evaluating Children's Participation in SEN Procedures: Lessons for educational psychologists. Educational Psychology in Practice, 22 (3), p. 255-271.

Pinkus, S. (2005). Bridging the gap between policy and practice: adopting a strategic vision for partnership working in special education. British Journal of Special Education, 32(4), p. 184-187.

Rozporządzenie MEN z 17.11.2010 w sprawie warunków organizowania kształcenia, wychowania $i$ opieki dla dzieci i młodzieży niepetnosprawnych oraz niedostosowanych spolecznie $w$ przedszkolach, szkołach i oddziałach ogólnodostępnych lub integracyjnych. Dz. U. Nr 228, poz. 1490. a

Rozporzadzenie Ministra Edukacji Narodowej z dnia 17 listopada 2010 r. w sprawie zasad udzielania i organizacji pomocy psychologiczno-pedagogicznej w publicznych przedszkolach, szkołach i placówkach. Dz. U. nr 228, poz. 1487. b

Rozporzadzenie Ministra Edukacji Narodowej z dnia 17 listopada 2010 roku w sprawie szczegótowych zasad działania publicznych poradni psychologiczno-pedagogicznych, w tym publicznych poradni specjalistycznych. Dz.U. nr 228 poz. 1488. c

Rozporzadzenie Ministra Edukacji Narodowej z dnia 18 września 2008 r. w sprawie orzeczeń i opinii wydawanych przez zespoły orzekajace działajace w publicznych poradniach psychologiczno-pedagogicznych. Dz. U. Nr 173, poz. 1072.

Soar, K, Gersch, I.S., Lawrence, J. A,. (2006). Pupil involvement in special educational needs disagreement resolution: a parental perspective. Support for Learning, 2( 3), p. 149-155,

Walsh, L., de Paor, S. (2000). Partnership in Progress: Special and Ordinary Schools Working Together. REACH Journal of Special Needs Education in Ireland, 13(2), p. 77-82. 
Walther-Thomas, Ch. S. (1997). Co-teaching experiences: The benefits and problems that teachers and principals report over time. Journal of Learning Disabilities, 30(4), p. 395-407.

Westwood, P. (2002). Commonsense methods for children with special needs. Strategies for the regular classroom. London and New York, England and USA: RoutledgeFalmer.

Winter, E., Kilpatrick, R. (1998). Code of Practice: The Northern Ireland Context. REACH Journal of Special Needs Education in Ireland, 11(2), p. 82-91.

Woolfson, C., Truswell, E. (2005). Do classroom assistant work? Educational Research, 47(1), p. 63-75.

Zamkowska, A. (2009). Wsparcie edukacyjne uczniów z upośledzaniem umysłowym w stopniu lekkim w różnych formach kształcenia na I etapie edukacji. Radom, Poland: Wyd. Politechniki Radomskiej. 